\title{
Inactivation of beta1 integrin induces proteasomal degradation of
} Myc oncoproteins

\author{
Manabu Sasada ${ }^{1,2,3,4}$, Takuya Iyoda ${ }^{1,5}$, Tatsufumi Asayama ${ }^{1}$, Yusuke Suenaga $^{4}$, \\ Shunsuke Sakai ${ }^{1}$, Naoya Kase ${ }^{1}$, Hiroaki Kodama ${ }^{6}$, Sana Yokoi ${ }^{4}$, Yoichiro Isohama ${ }^{2,3}$ \\ and Fumio Fukai ${ }^{1,2}$

\footnotetext{
${ }^{1}$ Department of Molecular Pathophysiology, Faculty of Pharmaceutical Sciences, Tokyo University of Science, Chiba, Japan

${ }^{2}$ Translational Research Center, Research Institute of Science and Technology, Tokyo University of Science, Chiba, Japan

${ }^{3}$ Laboratory of Applied Pharmacology, Faculty of Pharmaceutical Sciences, Tokyo University of Science, Chiba, Japan

${ }^{4}$ Cancer Genome Center, Chiba Cancer Center Research Institute, Chiba City, Chiba, Japan

${ }^{5}$ Department of Pharmacy, Faculty of Pharmaceutical Sciences, Sanyo-Onoda City University, Sanyo-Onoda City, Yamaguchi, Japan

${ }^{6}$ Faculty of Science and Engineering, Saga University, Saga, Japan
}

Correspondence to: Fumio Fukai, email: fukai@rs.noda.tus.ac.jp

Keywords: integrin; Myc; proteasomal degradation; fibronectin; neuroblastoma

Abbreviations: ECM: extracellular matrix; Ab: antibody; mAb: monoclonal antibody; FN: fibronectin

Received: February 03, $2019 \quad$ Accepted: July 15, $2019 \quad$ Published: August 13, 2019

Copyright: Sasada et al. This is an open-access article distributed under the terms of the Creative Commons Attribution License 3.0 (CC BY 3.0), which permits unrestricted use, distribution, and reproduction in any medium, provided the original author and source are credited.

\section{ABSTRACT}

The MYC family oncogenes (MYC, MYCN, and MYCL) contribute to the genesis of many human cancers. Among them, amplification of the MYCN gene and overexpression of $\mathrm{N}$-Myc protein are the most reliable risk factors in neuroblastoma patients. On the other hand, we previously found that a peptide derived from fibronectin, termed FNIII14, is capable of inducing functional inactivation in $\beta 1-$ integrins. Here, we demonstrate that inactivation of $\beta 1$-integrin by FNIII14 induced proteasomal degradation in N-Myc of neuroblastoma cells with MYCN amplification. This $\mathrm{N}$-Myc degradation by FNIII14 reduced the malignant properties, including the anchorage-independent proliferation and invasive migration, of neuroblastoma cells. An in vivo experiment using a mouse xenograft model showed that the administration of FNIII14 can inhibit tumor growth, and concomitantly a remarkable decrease in $\mathrm{N}$-Myc levels in tumor tissues. Of note, the activation of proteasomal degradation based on $\beta 1$-integrin inactivation is applicable to another Myc family oncoprotein, c-myc, which also reverses cancer-associated properties in pancreatic cancer cells. Collectively, $\beta 1$-integrin inactivation could be a new chemotherapeutic strategy for cancers with highly expressed Myc. FNIII14, which is a unique pharmacological agent able to induce $\beta 1$-integrin inactivation, may be a promising drug targeting Myc oncoproteins for cancer chemotherapy.

\section{INTRODUCTION}

The Myc family of oncogenes encode three kinds of transcription factor proteins (c-, N-, and L-myc) that are involved in physiological cellular processes, including cell proliferation and several metabolic pathways $[1,2]$; their expression is strictly controlled in normal cells [3].
However, Myc proteins, once they are excessively expressed, cause a variety of cancer-associated aggressive properties, such as dysregulated survival and proliferation and drug-resistance in cancer cells $[1,2,4,5]$. Among the Myc family of oncoproteins, over-expression of N-Myc is restricted in some cancers, including neuroblastoma, a common pediatric cancer. Neuroblastoma patients with 
the $M Y C N$ gene amplification are classified into the highrisk group, and their survival rates remain in the range of $30 \%-40 \%$, which represents the highest number of cancerrelated deaths among pediatric solid cancers $[6,7]$. On the other hand, over-expression of c-myc is found in a variety of cancers, such as small cell lung cancer and pancreatic cancer, and plays a crucial role in their pathogenesis [8-10]. Thus, the Myc family of oncoproteins are considered to be important target molecules for cancer chemotherapy $[2,4,7]$. However, attempts to develop a drug targeting the Myc family of oncoproteins have failed because they are non-enzymatic transcription factors lacking a specific active site for small molecules, thus making it difficult to inhibit their activity $[11,12]$.

Cell adhesion to the extracellular matrix (ECM), mainly mediated by $\beta 1$-integrins, is a critical event for cell regulation, including survival, proliferation, differentiation, and gene expression [13-15]. We previously found that fibronectin harbors a cryptic functional site within the molecular structure [16, 17]. A peptide derived from fibronectin, termed FNIII14, is capable of inducing conformational change in $\beta 1$-integrins necessary for their functional inactivation. FNIII14 greatly influences the anchorage-dependent cellular functions through negative regulation of $\beta 1$-integrin-mediated cell signaling [18-20].

Here, we demonstrate that inactivation of $\beta 1$ integrin by FNIII14 induced proteasomal degradation in $\mathrm{N}-\mathrm{Myc}$ of human neuroblastoma cells with the $M Y C N$ gene amplification. This N-Myc protein degradation attenuated the cancer-associated malignant properties of neuroblastoma cells. An in vivo experiment using a mouse xenograft model showed the therapeutic potential of FNIII14 for aggressive neuroblastoma. Importantly, integrin inactivation-based proteasomal degradation was shown to be applicable to another MYC family oncoprotein, c-myc, which is over-expressed in a variety of malignant tumors, such as small cell lung cancer and pancreatic cancer. The present study provides insights into the potential pharmacological application of FNIII14 as an antitumor agent against cancers with highly expressed Myc oncoproteins.

\section{RESULTS}

\section{FNIII14 induces a remarkable decrease in $\mathrm{N}$-Myc protein levels in neuroblastoma cells based on proteasomal degradation}

IMR-32 cells were used in this study as a human neuroblastoma cell line with $M Y C N$ gene amplification. Similar to our previous results using various cell types $[18,20]$, FNIII14 also weakened the adhesion of IMR-32 cells to the fibronectin substrate (Supplementary Figure $1 \mathrm{~A})$ through inactivation of $\beta 1$-integrins (Supplementary Figure 1B). We then examined the effect of the FNIII14- induced $\beta 1$-integrin inactivation on IMR-32 cell growth on the fibronectin substrate. When IMR-32 cells were cultured for 5 days in the presence or absence of FNIII14, IMR-32 cell proliferation was suppressed in a dosedependent manner (Figure 1A). Since N-Myc protein serves as a transcription factor that activates the expression of pro-proliferative genes [21], we examined the effect of FNIII14 treatment on the expression of the MYCN gene and N-Myc protein. As shown in Figure 1B, no significant change was detected in the expression of MYCN gene by FNIII14 when evaluated by real-time PCR. In contrast, western blot analysis showed a remarkable decrease in N-Myc protein level after FNIII14 treatment (Figure 1C). This decrease in N-Myc protein levels by FNIII14 was time-dependent and a marked decrease was observed after 6 days of incubation (Figure 1D). The FNIII14-induced decrease in N-Myc protein was reproducible in other human $M Y C N$-amplified neuroblastoma cell lines, such as NB-1 cells and KELLY cells. (Supplementary Figure 2).

To examine the involvement of targeted degradation in the FNIII14-induced decrease of N-Myc, we tested the effect of MG-132, a proteasome inhibitor, on the decrease of N-Myc. As shown in Figure 2A, the decrease in N-Myc protein level induced by FNIII14 was completely canceled by the addition of MG-132. Moreover, an immunoprecipitation study using anti-N-Myc antibody (Ab) further showed that FNIII14 treatment markedly elicited ubiquitination of N-Myc in IMR-32 cells (Figure 2B). Thus, FNIII14 was shown to induce N-Myc protein degradation through activation of the ubiquitinproteasome system.

\section{Molecular basis of the proteasomal degradation of N-Myc protein induced by FNIII14}

We investigated the involvement of integrins on the FNIII14-induced N-Myc degradation. First, we examined whether the expression of integrin with high affinity to fibronectin was altered in the course of FNIII14 treatment. As shown in Figure $2 \mathrm{C}$, clear $\beta 1$ gene expression was observed and that of its counterparts $\alpha 4$ and $\alpha \mathrm{v}$ but $\alpha 5$ was not detected. RT-PCR showed that gene expression of integrin subunits, $\alpha 4, \alpha \mathrm{v}$, and $\beta 1$, were barely changed by FNIII14 treatment (Figure 2C). Because FNIII14 was found to be a factor that inactivates $\beta 1$-integrins [18], $\beta 1$ subunit was also analyzed at the protein level. As shown in Figure 2D, the expression levels of the $\beta 1$ subunit detected by western blotting was not altered by FNIII14.

We next investigated whether inactivation of $\beta 1$ integrins was responsible for the proteasomal degradation of N-Myc induced by FNIII14. The effects of two different factors, which are able to activate $\beta 1$-integrins, were examined. Divalent metal ions including $\mathrm{Mn}^{2+}$ [22] are known to widely activate integrins [22], and HUTS-4, a monoclonal antibody (mAb) that recognizes the active conformation-specific epitope, can specifically activate 


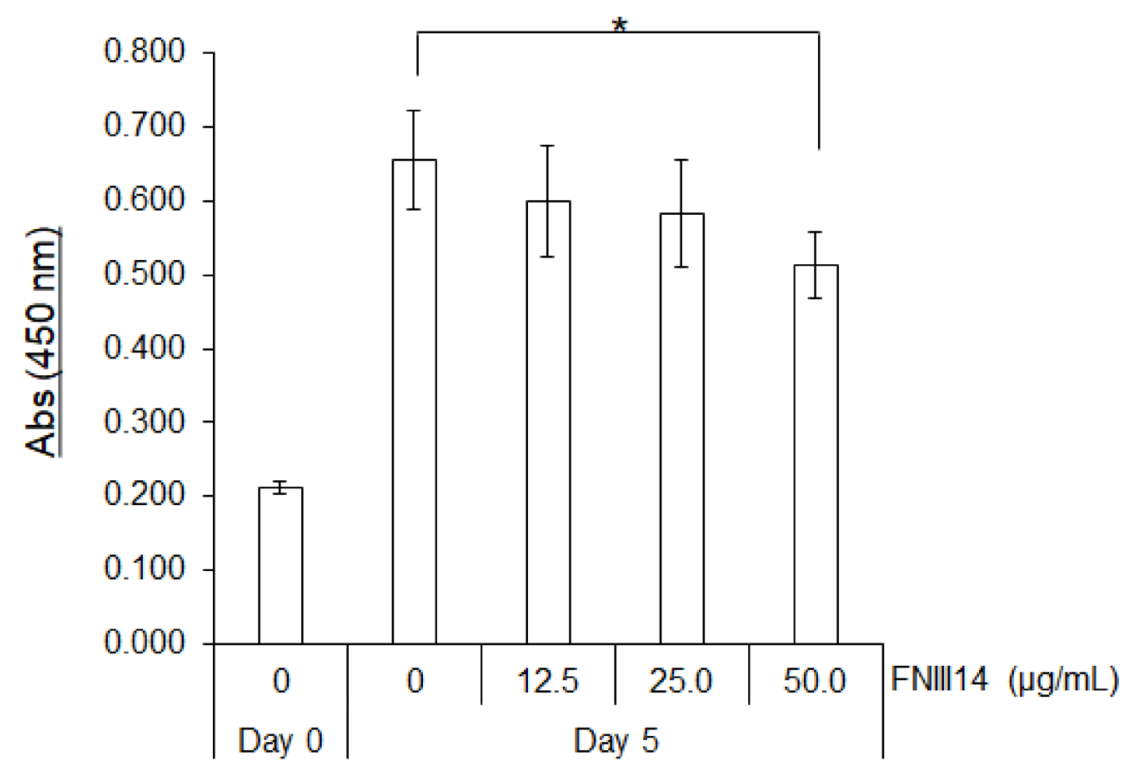

B

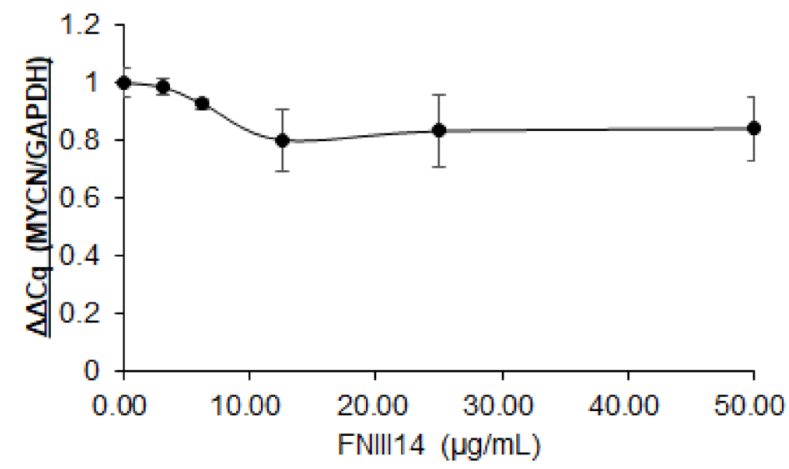

C

FNIII14 $(\mu \mathrm{g} / \mathrm{mL}) \quad-\quad 3.13 \quad 6.25 \quad 12.5 \quad 25.0 \quad 50.0$

N-Myc

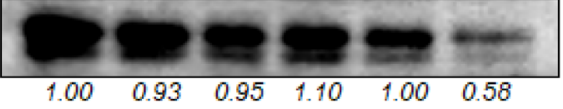

$\beta$-actin

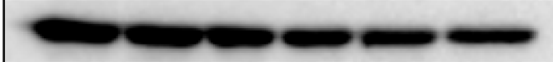

D

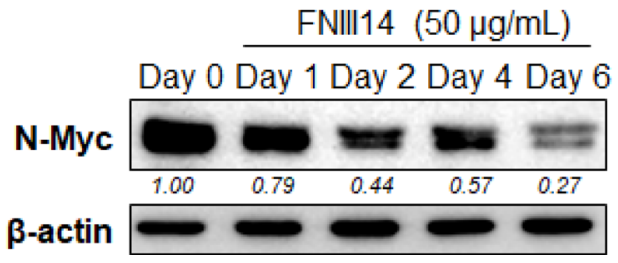

Figure 1: FNIII14 induces a reduction of N-Myc protein levels. (A) Effect of FNIII14 for proliferation of IMR-32 cells. IMR-32 cells adhered on the fibronectin substrate were stimulated with or without FNIIII4 $(50 \mu \mathrm{g} / \mathrm{mL})$ for 5 days and then subjected to the WST assay, as described in 'Materials and Methods'. Each point represents the mean \pm S.D. of triplicate determinations, ${ }^{*} P<0.05$. (B and $\mathbf{C}$ ) Effect of FNIIII4 on the expression of MYCN gene and N-Myc protein. IMR-32 cells were stimulated with the indicated concentrations of FNIII14 for 6 days and then subjected to real-time PCR (B) or Western blot analysis (C). (D) Time-dependent decrease in N-Myc protein levels by FNIII14. IMR-32 cells were stimulated with FNIIII4 $(50 \mu \mathrm{g} / \mathrm{mL})$ for the indicated days and then subjected to Western blot analysis to detect N-Myc protein. In (C) and (D), the intensity of the immunoblot was quantified densitometrically and represented as relative intensity. 
$\beta 1$-integrins $[22,23]$. As shown in Figure $2 \mathrm{E}$ and $2 \mathrm{~F}$, the FNIII14-induced decrease in N-Myc protein level was reversed by the addition of either $\mathrm{MnCl}_{2}$ or HUTS-4, suggesting that $\beta 1$-integrin inactivation was responsible for the FNIII14-induced proteasomal degradation of N-Myc. On the other hand, treatment with the peptides CS-1 and GRGDSP, which are specific antagonists for the fibronectin receptors expressed on IMR-32 cells, such as integrin $\alpha 4 \beta 1$

A

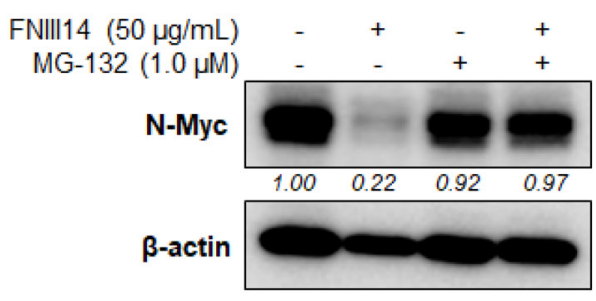

$\begin{array}{rllll}\text { FNIII14 }(50 \mu \mathrm{g} / \mathrm{mL}) & - & + & - & - \\ M G-132(1.0 \mu \mathrm{M})) & - & - & + & + \\ \text { Control } \lg G(5.0 \mu \mathrm{g} / \mathrm{mL}) & - & - & - & - \\ \text { ti-N-Myc } \lg G(5.0 \mu \mathrm{g} / \mathrm{mL}) & - & - & - & -\end{array}$

C
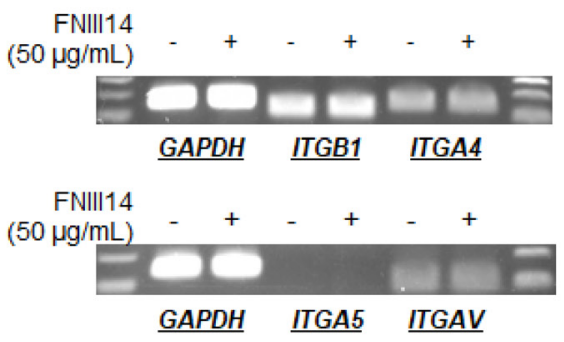

E

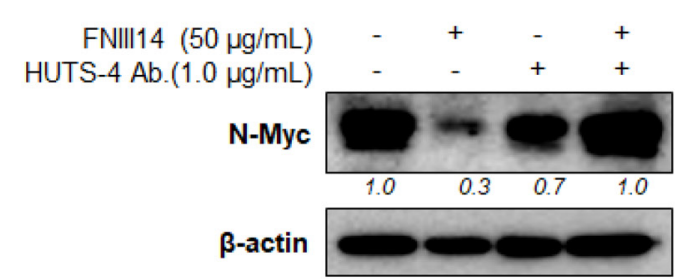

B and $\alpha v \beta 1$, respectively, barely influenced N-Myc protein levels (Figure 2F). These results thus indicated that the conformational and consequent functional inactivation of $\beta 1$-integrins, but not the prevention of $\beta 1$-integrin ligation by integrin antagonists, is essentially required to induce the proteasomal degradation of N-Myc protein.

The signaling pathway for triggering the proteasomal degradation of N-Myc protein was investigated. Analysis
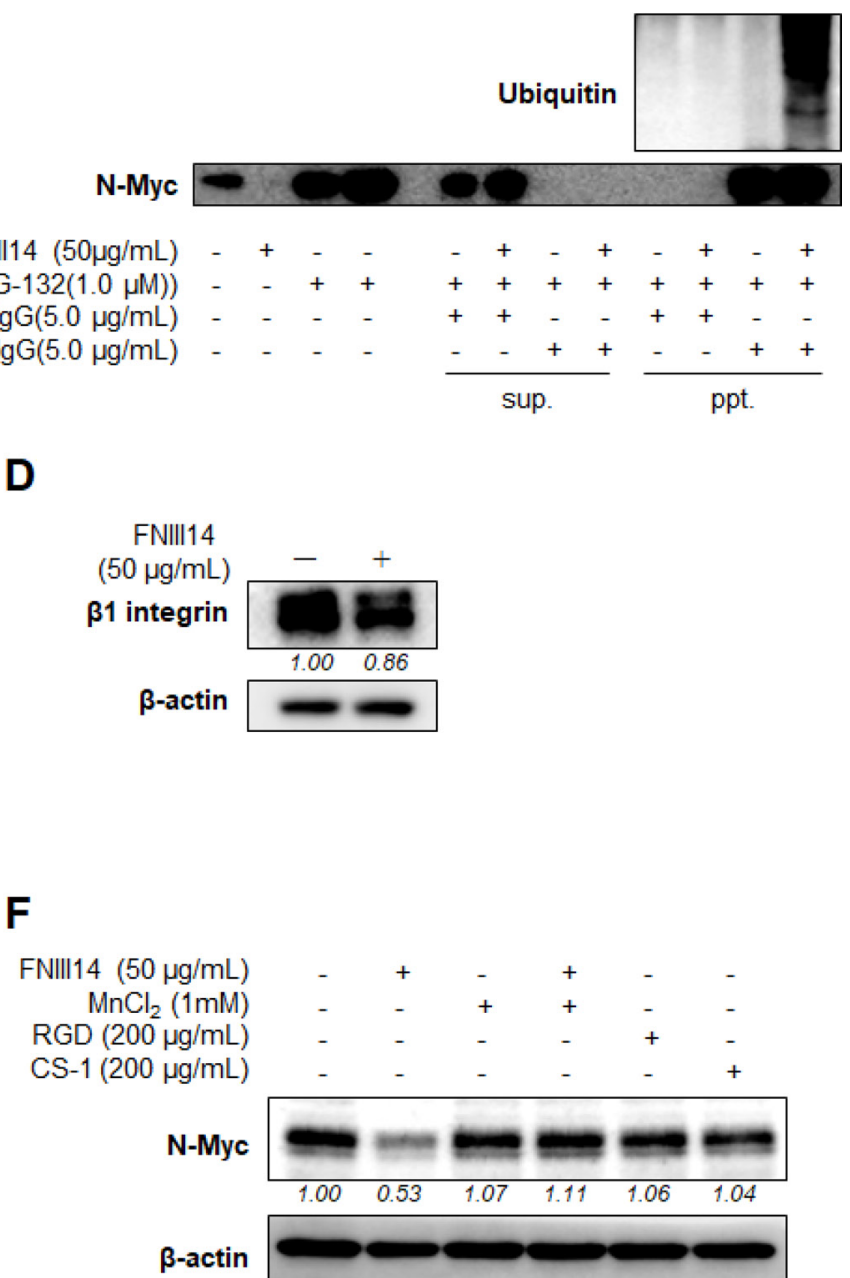

Figure 2: FNIII14 induces proteasomal degradation of $\mathrm{N}-\mathrm{Myc}$ protein through inactivation of $\beta 1$-integrins. (A and $\mathrm{B}$ ) Involvement of proteasomal degradation in FNIII14-induced decrease in N-Myc protein. IMR-32 cells were cultured in the presence or absence of FNIII14 $(50 \mu \mathrm{g} / \mathrm{mL})$. MG-132, a proteasome inhibitor, was added to this culture on day 5, and cell lysates on day 6 were subjected to Western blot analysis using N-Myc Ab (A). Immunoprecipitation study using anti-N-Myc Ab was performed in (B), as described in "Material and Methods". Cell lysates were also subjected to immunoblot analysis to detect ubiquitination of N-Myc protein. (C) Effect of FNIII14 on gene expression of integrin subunits. IMR-32 cells stimulated with or without FNIII14 $(50 \mu \mathrm{g} / \mathrm{mL})$ for 6 days were subjected to RT-PCR to detect integrin gene of $\beta 1$ (ITGB1), $\alpha 4$ (ITGA4), $\alpha 5$ (ITGA5) and $\alpha \mathrm{v}$ (ITGAV). (D) Effect of FNIII14 on integrin $\beta 1$ protein expression. IMR-32 cells treated as in (C) were subjected to Western blot analysis to detect N-Myc protein. (E and F) Involvement of $\beta 1$ integrin inactivation in FNIII14-induced N-Myc protein degradation. IMR-32 cells were stimulated with or without FNIII14 $(50 \mu \mathrm{g} / \mathrm{mL})$ in the presence or absence of factors that affect the $\beta 1$-mediated cell adhesion: HUTS- $4=\beta 1$-integrin-activating $\mathrm{mAb}, \mathrm{MnCl} 2=$ integrin activator, RGD and CS-1 = antagonistic peptides for integrin $\alpha v \beta 1$ and $\alpha 4 \beta 1$, respectively. After 6 days of culture, cells were subjected to Western blot analysis using anti-N-Myc Ab. In (A) and (D-F), the intensity of the immunoblots was quantified densitometrically and represented as relative intensity. 
of the signaling pathway downstream of $\beta 1$-integrin showed that $\beta 1$-integrin inactivation by FNIII14 was accompanied by the dephosphorylation of Akt at Ser473 and GSK3 $\beta$ at Ser9 (Figure 3A), both of which are known to serve as a driving signal to enhance the proteasomal degradation of N-Myc by facilitating the ubiquitination of N-Myc [24]. We next examined the protein expression of Fbxw7, an E3-ubiquitin ligase for N-Myc protein $[25,26]$, by inducing targeted degradation via the ubiquitin proteasome system. As shown in Figure 3B, IMR-32 cells treated with FNIII14 upregulated the expression level of Fbxw7. Additionally, FNIII14 treatment also induced downregulation in the expression of Aurora A (Figure 3B), which inhibits proteasomal degradation by binding to N-Myc protein [25]. These results showed that $\beta 1$-integrin inactivation by FNIII14 accelerated the proteasomal degradation of N-Myc by promoting not only ubiquitination of N-Myc, but also its access to the proteasome complex.

\section{FNIII14-induced N-Myc protein degradation causes attenuation of cancer-associated malignant properties of neuroblastoma cells}

Excessive expression of N-Myc contributes to the cancer-associated malignant properties of high-risk neuroblastoma cells [4, 27, 28]. Therefore, FNIII14induced N-Myc protein degradation is expected to cause attenuation of the malignant properties in neuroblastoma cells. As shown in Figure 4A, untreated cells grew in soft agarose and more than 100 colonies were formed, but the cells treated with FNIII14 showed attenuated ability to grow in soft agarose, and the number of colonies represented less than half the untreated cells. An in vitro invasion assay also showed that FNIII14 treatment suppressed the ability of invasion through the basement membrane-like matrix EHS-gel (Figure 4B).

Based on these in vitro results, the therapeutic potential of FNIII14 was tested using a mouse xenograft model for human high-risk neuroblastoma. After transplanting IMR-32 cells, mice bearing tumors were divided into two groups: the control-group was administered with vehicle and the FNIII14-group with the peptide FNIII14. Mice were injected daily with vehicle or FNIII14 for one week and then monitored for tumor growth. After monitoring for 5 weeks, tumors were removed, and their lysates were subjected to western blot analyses of N-Myc protein levels. As shown in Figure $5 \mathrm{~A}$ and $5 \mathrm{~B}$, the administration of FNIII14 significantly delayed tumor growth even though chemotherapy lasted only one week. This tumor growth inhibition was in parallel with a marked decrease in N-Myc protein levels in tumor tissues (Figure 5D). No significant weight loss or tissue damage was observed in mice after the administration of FNIII14 (Figure 5C). These results indicated that FNIII14 has a therapeutic potential for neuroblastomas with $M Y C N$ gene amplification.

\section{Proteasomal degradation based on integrin- inactivation is applicable for degradation of c-myc protein.}

The amino acid sequences of the Myc family of proteins, especially the Myc box domain involved in proteasomal degradation [11], are highly conserved between each protein. This prompted us to presume that $\beta 1$-integrin inactivation by treatment with FNIII14 induces proteasomal degradation in another Myc family protein, c-myc, which is highly expressed in a wide variety of cancers. The pancreatic cancer cell line MIA-
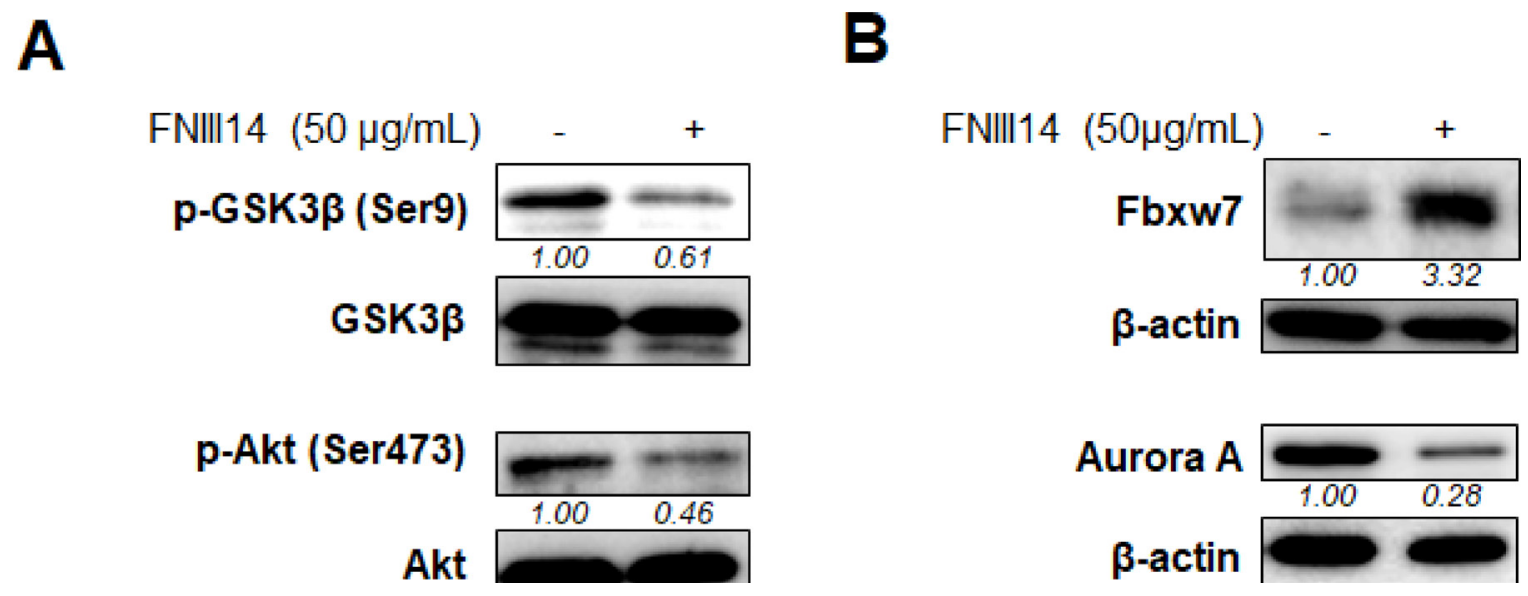

Figure 3: Molecular basis of proteasomal degradation of N-Myc protein induced by FNIII14. IMR-32 cells adhered on the fibronectin substrate were cultured with or without FNIII14 $(50 \mu \mathrm{g} / \mathrm{mL})$ for 6 days. Cell lysates were subjected to Western blot analysis. (A) Effects of FNIII14 for phosphorylation levels of GSK3 $\beta$ at Ser9 and Akt at Ser473. (B) Effects of FNIII14 for intracellular level of Fbxw7 protein and Aurora A protein. The intensity of the immunoblot was quantified densitometrically and represented as relative intensity. 
PaCa 2 and small cell lung cancer cell line NCI-H82 were used as cancer cells with high expression of c-myc protein. FNIII14 treatment of MIA-PaCa 2 cells induced a significant decrease in c-myc protein level and was canceled by the addition of MG-132 (Figure 6A). Similarly, FNIII14 treatment decreased the c-myc protein level in NCI-H82 cells and K562 cells; this change was abrogated by MG-132 (Figure 6B and 6C). Moreover, the addition of factors capable of activating $\beta 1$-integrin, namely, HUTS-4 Ab and $\mathrm{MnCl}_{2}$, abrogated the effect of FNIII14 (Figure 6D). FNIII14 treatment also attenuated the ability of MIA-PaCa 2 cells to grow in soft agarose (Figure 6E). It was thus demonstrated that $\beta 1$-integrin inactivation by FNIII14 was also responsible for proteasomal degradation of c-myc protein, which caused attenuation of the cancer-associated malignant properties.

Collectively, $\beta 1$-integrin inactivation seems to be common signaling that induces proteasomal degradation
A

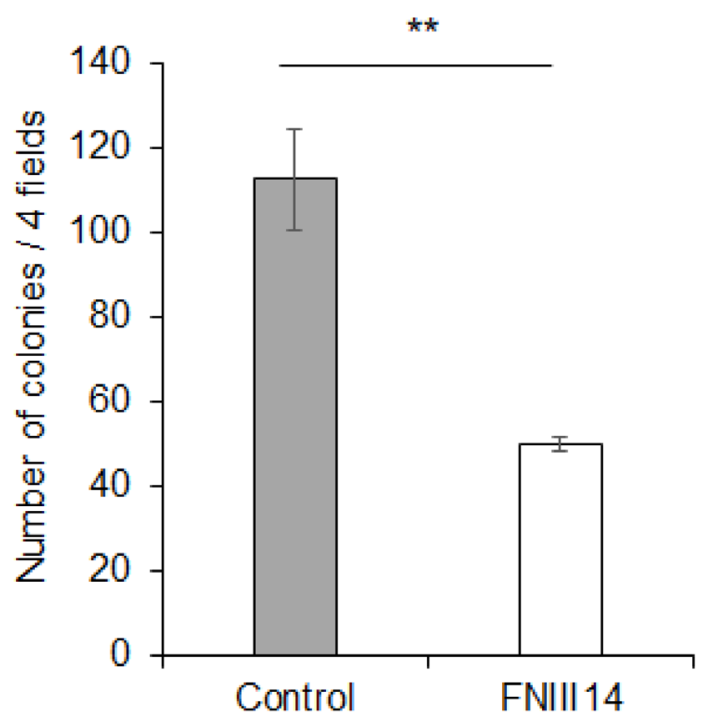

C

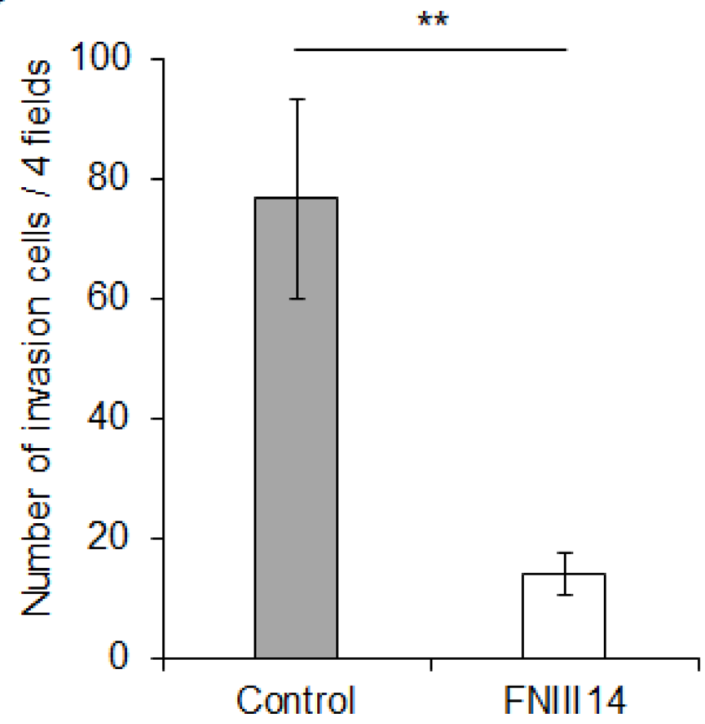

B

a

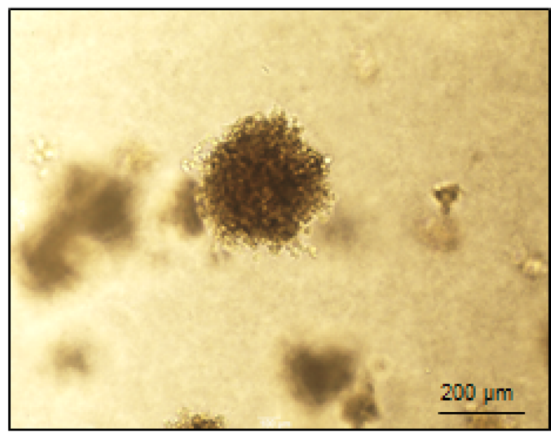

b

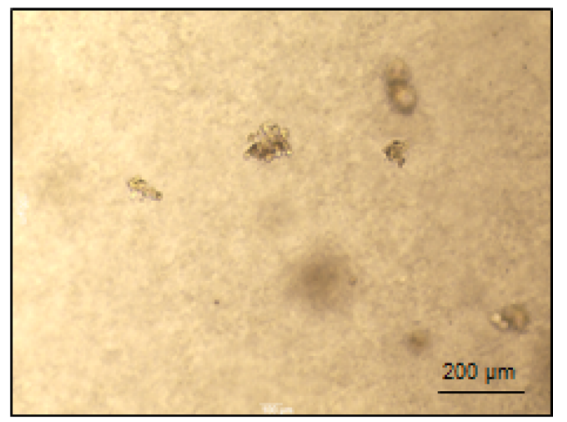

Figure 4: FNIII14 has the ability to attenuate cancer-related malignant properties. (A and B) Effect of FNIII14 on anchorageindependent cell growth. IMR-32 cells treated with (gray bar) or without FNIII14 (open bar) for 6 days were subjected to the colony formation assay as described in 'Materials and Methods'. (A): Number of colonies formed after 3 weeks. (B): Representative images of colonies in "Control" (without FNIII14) (a) and "FNIII14" (with FNIII14) (b). (C) Effect of FNIII14 on the invasion ability of IMR-32. IMR-32 cells treated with (gray bar) or without FNIII14 (open bar) for 6 days were subjected to the in vitro invasion assay as described in 'Materials and Methods'. Each point represents the mean \pm S.D. of triplicate determinations, ${ }^{* *} P<0.01$. 
of Myc family oncoproteins, and consequently causes a significant reduction in the cancer-associated malignant properties. FNIII14, which is a unique peptide factor capable of inactivating $\beta 1$-integrins, may be useful for chemotherapeutic treatment of malignant tumors with high expression of Myc oncoproteins.

\section{DISCUSSION}

The Myc family of oncoproteins plays crucial roles in the cancer-associated aggressive feature of malignant tumors. Therefore, these oncoproteins have been implicated as important targets for cancer chemotherapy. However, there are no effective agents that directly target Myc oncoproteins. First, this is because the Myc proteins are non-enzymatic transcription factors that lack a specific active site for small molecules [12]. Second, because Myc proteins are present inside the cells, cytoplasm, and nuclei, direct targeting of these proteins by middle or large molecular strategies is problematic. In the present study, we demonstrated the induction of proteasomal degradation in N-Myc protein by inactivation of $\beta 1$-integrins. Since FNIII14 markedly decreased the intracellular levels of N-Myc in aggressive neuroblastoma cells and

\section{A}
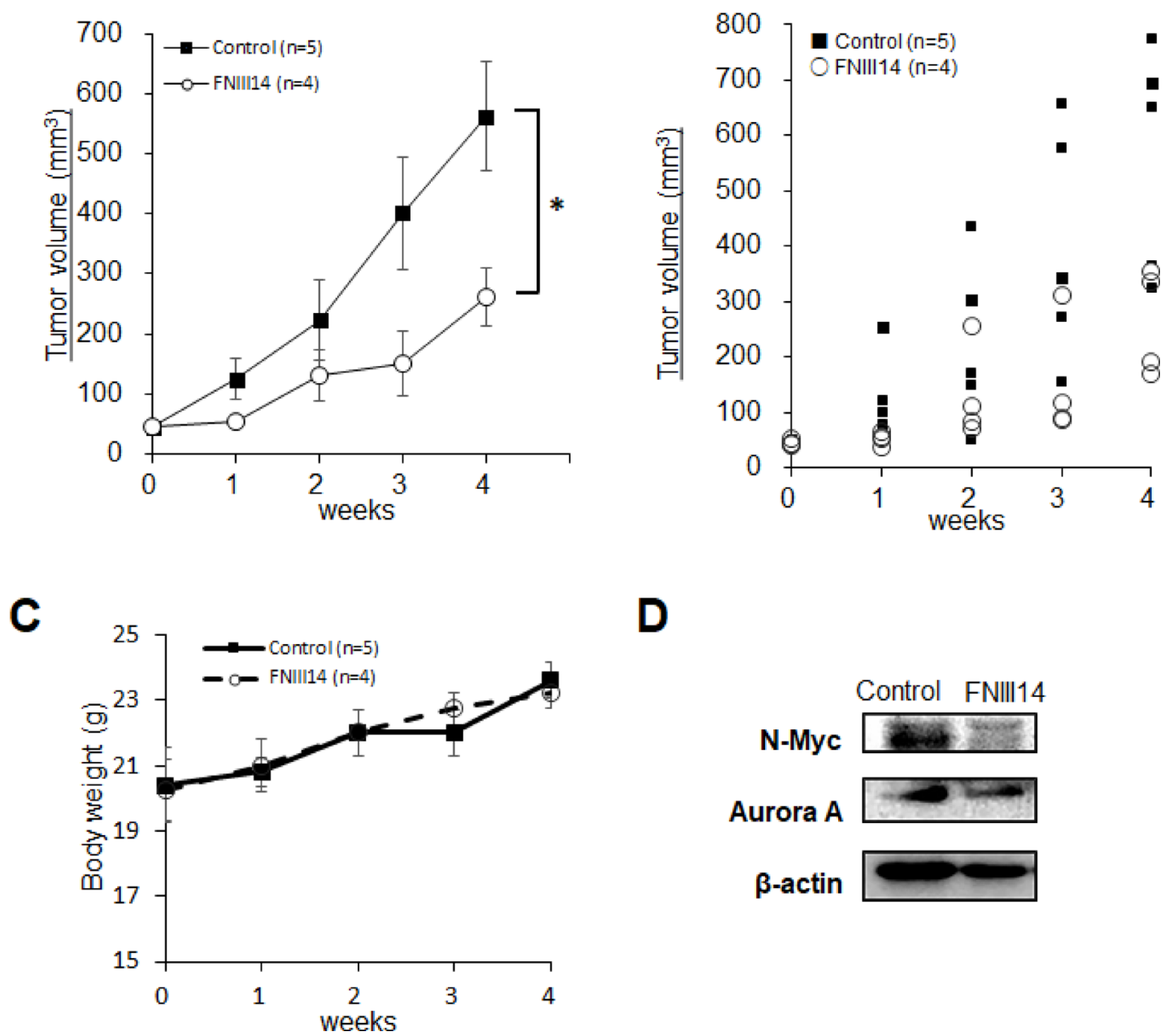

D

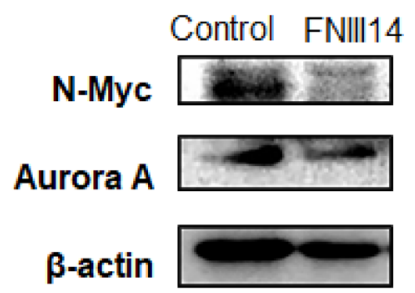

Figure 5: Administration of FNIII14 suppresses tumor growth in neuroblastoma xenograft model. IMR-32 cells $(2.0 \times$ $10^{6}$ cells/head) suspended in MEM containing EHS-gel were subcutaneously injected into the left flank of Balb/c nude mice. Mice bearing established tumors were divided into two groups: the Control group was administered vehicle and the FNIII14 group was administered peptide FNIII14, as described in the Materials and Methods. Chemotherapy was initially carried out for 1 week. Tumor volume (mm $\left.{ }^{3}\right)$ was determined by measuring with calipers and calculated according to hemi-ellipsoid model: Volume $=2 / 3 \times \pi \times($ major axis $/ 2) \times($ minor axis $/ 2)^{2}$. Three weeks after chemotherapy, tumors removed from mice were subjected to western blot analysis to detect N-Myc and Aurora A as described in the 'Materials and Methods'. (A) Tumor growth curves for IMR-32 xenografts (Control group, $n=5$; FNIII14 group, $n$ =4). Tumor volumes are shown as means \pm S.E. Data was analyzed by Mann-Whitney $U$-test. (B) Representative dot plots showing the tumor volume for each week. (C) Body weight of each group. (D) Expression of N-Myc and Aurora A proteins in tumor tissues of the Control and FNIII14 groups. 
remarkably reduced the cancer-associated malignant properties, FNIII14-induced $\beta 1$-integrin inactivation could be considered to be functional for the targeting of $\mathrm{N}-\mathrm{Myc}$ oncoprotein. In fact, an in vivo experiment using a xenograft model showed the therapeutic potential of FNIII14 for chemotherapeutic treatment of neuroblastoma. Notably, $\beta 1$-integrin inactivation-based activation of the ubiquitin-proteasome system could be adopted for another Myc family protein, c-myc, which is highly expressed in a variety of cancers. Since the effect of FNIII14 is mediated by its receptor proteins present on cell surfaces [29], this peptide factor would be able to easily initiate the degradation of Myc oncoproteins independently of their subcellular localization. FNIII14, which is a unique pharmacological agent able to induce $\beta 1$-integrin inactivation, may be promising as a drug that targets the Myc oncoproteins for chemotherapeutic treatment of cancers that show high expression of Myc oncoproteins.

B
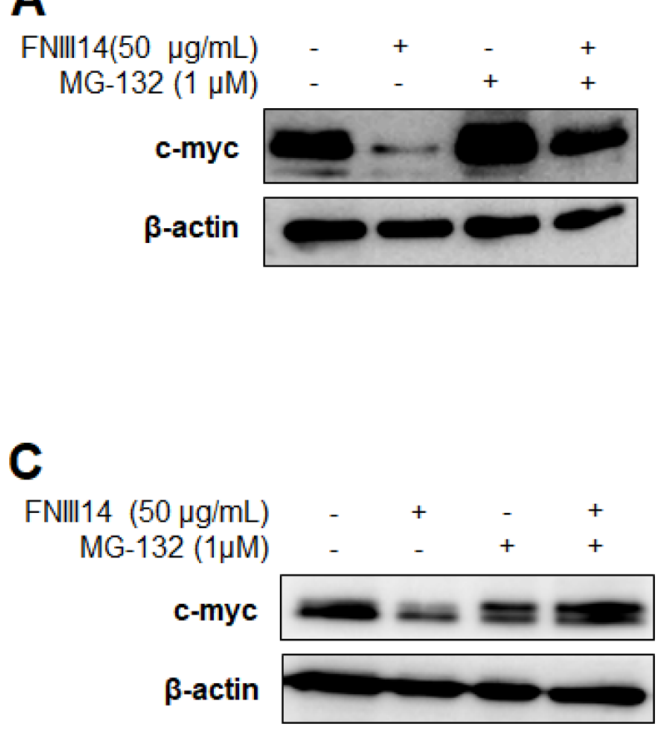

D

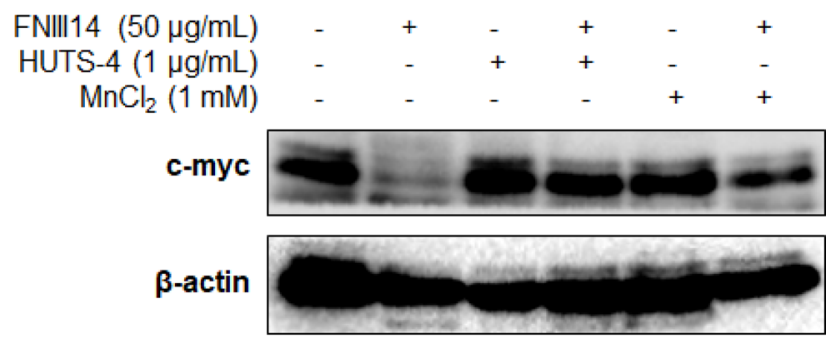

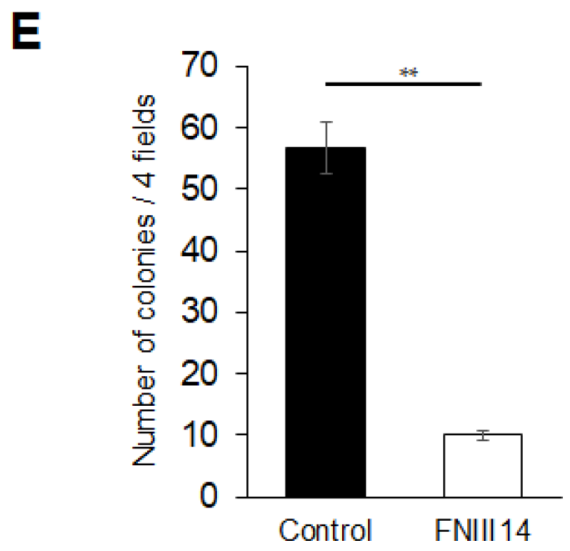

Figure 6: FNIII14 is able to induce degradation of c-myc as well as N-Myc. (A-C) Induction of proteasome-dependent degradation of c-myc protein by FNIII14. Various cancer-derived cell lines (Pancreatic cancer MIA-PaCa 2 cells in (A), small cell lung cancer NCI-H82 cells in (B) and chronic myelogenous leukemia K562 cells in (C)) were cultured with each medium in the presence or absence of FNIII14 in the same manner as in the case of neuroblastoma cells IMR-32. MG-132 was similarly added one day before the end of FNIII14 treatment and treated for 24 hours. (D) Involvement of $\beta 1$-integrin inactivation in FNIII14-induced c-myc protein degradation. MIA-PaCa 2 cells were stimulated with FNIII14 in the presence or absence of factors capable of $\beta 1$-integrin activation, HUTS-4 and $\mathrm{MnCl2}$. (E) Effect of FNIII14 on the anchorage-independent growth of MIA-PaCa 2 cells. MIA-PaCa 2 cells were subjected to the colony formation assay as described in 'Materials and Methods'. 
Mechanistic analysis revealed that two different molecular pathways are functional in the FNIII14induced proteasomal degradation of N-Myc. One route was in the Akt/GSK3 $\beta$ signaling pathway downstream of $\beta 1$-integrin. As has been established, $\beta 1$-integrin-mediated adhesive interaction induces Akt phosphorylation at Ser473 [30], which in turn suppresses the phosphorylation of Thr58 of N-Myc by GSK3 $\beta$, resulting in prevention of the proteasomal degradation of Myc proteins. By inhibiting this pathway, FNIII14 successively stimulates the proteasomal degradation of Myc proteins. Another route is in the quantitative regulation of Fbxw7 and Aurora A expression levels. Fbxw7 is an E3 ligase that catalyzes ubiquitination of Myc family proteins, which facilitates the access to the proteasome complex [26], while Aurora A stabilizes Myc oncoproteins by inhibiting this molecular interaction [24]. Stimulation with FNIII14 not only upregulates the expression of Fbxw7, but also downregulates the expression of Aurora A in neuroblastoma cells. Thus, FNIII14 stimulated these different pathways concomitantly, making the degradation of N-Myc protein highly efficient. However, in contrast to the integrin/Akt/GSK3 $\beta$ pathway, the signaling pathway leading to changes in the expression of Fbxw7 and Aurora A, following the FNIII14-induced inactivation of $\beta 1$-integrins has yet to be solved. Furthermore, recent studies demonstrate that additional factors, such as Ras/ ERK, prolyl isomerase PIN-1, phosphatase PP2A, and PP2A inhibitor CIP2A/KIKA154 play important roles in the degradation and stabilization of Myc [31]. In order to elucidate the molecular mechanism of Myc degradation based on FNIII14-induced integrin inactivation, we must analyze the involvement of these functional molecules. A precise understanding of the signaling pathway would provide the molecular basis for the development of a more efficient cancer treatment targeting Myc oncoproteins.

This study demonstrated the particular importance of the inactivation of $\beta 1$-integrins by FNIII14 for targeting Myc proteins. Since integrin-mediated cell adhesion to the ECM is essential for fundamental cell functions, including survival, proliferation, differentiation, and gene expression, $\beta 1$-integrin inactivation by FNIII14 may exhibit strong cytotoxic effects on normal cells. However, cells in tissues adhere to a variety of ECM components by using several membrane receptors, such as the $\beta 2-6$ subfamily of integrins and transmembrane proteoglycans. It seems that $\beta 1$-integrin inactivation by FNIII14 is unable to induce cell detachment, but does induce de-adhesion, which is defined as the process involving the transition of the cell from a strongly adherent state to a state of intermediate adherence [32]. Indeed, our previous studies suggest that FNIII14 exhibits no significant injurious effects but is rather beneficial on the host. Matsunaga et al. reported that FNIII14 treatment in combination with an anti-cancer drug enables eradication of acute myelogenous leukemia with no significant myelosuppression by abrogating cell adhesion-mediated drug resistance [20]. Therefore, it can be expected that FNIII14 is applicable as an anti-tumor agent for various malignant tumors. However, to completely remove cancer cells from the body, FNIII14 therapy may need to be used in combination with additional chemotherapy in the form of general anti-cancer drugs. Further investigation into this possibility is now in progress.

\section{MATERIALS AND METHODS}

\section{Reagents}

Plasma fibronectin was purified from horse serum as described previously [33]. Peptide FNIII14 (TEATITGLEPGTEYTIYVIAL) has been described previously [16]. Peptide GRGDSP and peptide CS-1, which were used as antagonists for integrin $\alpha 5 \beta 1$ and integrin $\alpha 4 \beta 1$ integrin, respectively, were purchased from Eurofin genetics (Tokyo, Japan). $\mathrm{MnCl}_{2} 4 \mathrm{H}_{2} \mathrm{O}$ was purchased from Tokyo Chemical Industry Co., Ltd. (Tokyo, Japan). We purchased anti-human N-Myc Ab (OP13) and anti-Ubiquitin Ab (04-263) from Merck Millipore (Darmstadt, Germany), and anti-Aurora A Ab (\#3092S), anti-Akt mAb (\#9272S), anti-phospho Akt(Tyr473) mAb (\#4051S), anti-GSK3ß Ab (\#9315S), anti-phospho GSK3 $\beta$ (Ser9) Ab (\#9323S), and anti-c-myc Ab (\#9402S) from Cell Signaling Technology Japan, K.K. (Tokyo, Japan). Anti-Fbxw7 Ab (ab109617) was purchased from Abcam (Tokyo, Japan). Anti- $\beta 1$ integrin mAbs recognizing active conformation AG89 and HUTS4 (MAB2079Z) were purchased from MBL Co., Ltd. (Nagoya, Japan) and Millipore, respectively. Proteasome inhibitor, MG-132 was obtained from Merck Millipore.

\section{Cell culture}

Human neuroblastoma cell line IMR-32, which was obtained from JCRB cell bank, was maintained in MEM (41500-018; Gibco, Grand Island, NY) supplemented with $10 \%$ FBS and penicillin-streptomycin solution. Human pancreatic cancer cell line MIA-PaCa 2 which was kindly provided by Dr. Masuho (Tokyo University of Science), was maintained in DMEM (Nissui Pharmaceutical Co., Ltd., Tokyo, Japan) plus 10\% FBS, 2 mM glutamine, penicillin-streptomycin solution, and $2.2 \mathrm{~g} / \mathrm{L} \mathrm{NaHCO}_{3}$. Human chronic myelogenous leukemia cell line K562 was obtained from the Resource Center for Biomedical Research, Institute of Development, Aging and Cancer, Tohoku University, and cultured with RPMI1640 medium plus 10\% FBS, 2 mM glutamine, penicillin-streptomycin solution, and $2.2 \mathrm{~g} / \mathrm{L} \mathrm{NaHCO}_{3}$. Human small cell lung cancer cell line NCI-H82 was kindly provided by Dr. Makinoshima (National Cancer Research Institute, Tokyo, Japan) and cultured with RPMI1640 medium (Nissui Pharmaceutical Co., Ltd.) supplemented with 10\% FBS, 
$2 \mathrm{mM}$ glutamine, penicillin-streptomycin solution, and $2.2 \mathrm{~g} / \mathrm{L} \mathrm{NaHCO}_{3}$. Human neuroblastoma cell line NB-1 was obtained from ATCC, cultured with RPMI1640 medium plus 10\% FBS, $2 \mathrm{mM}$ glutamine, penicillin-streptomycin solution, and $2.2 \mathrm{~g} / \mathrm{L} \mathrm{NaHCO}_{3}$. Human neuroblastoma cell line KELLY was deposited from Sigma-Aldrich Japan (Tokyo, Japan), was maintained in RPMI1640 medium supplemented with 10\% FBS, 2 mM glutamine, penicillin-streptomycin solution, and $2.2 \mathrm{~g} / \mathrm{L} \mathrm{NaHCO}$. Each experiment was carried out using thawed cells without further authentication. These cell lines were also authenticated by routine monitoring of cell morphology and proliferation, kept in a humidified incubator at $37^{\circ} \mathrm{C}$ with $5 \% \mathrm{CO}_{2}$, and cultured up to 15 passages.

\section{Cell survival and proliferation}

IMR-32 cells $\left(5.0 \times 10^{3}\right.$ cells/well $)$ were seeded on $96-w e l l$ plates coated with fibronectin $(2.0 \mu \mathrm{g} / \mathrm{mL})$. The number of viable cells was evaluated by the WST- 8 assay, as described previously [34].

\section{Colony formation assay}

Solution of a 1:1 mixture of 1.4\% Bacto-agar (BD Bioscience, Franklin Lakes, NJ) and $2 \times$ growth medium was poured into 12 -well plates. After solidification, IMR32 and MIA-PaCa $2\left(5.0 \times 10^{3}\right.$ cells/well $)$ suspended in growth medium containing $0.7 \%$ Bacto-agar in the presence or absence of FNIII14 were overlaid on top of a base layer. After solidification of the top agar layer, growth medium in the presence or absence of FNIII14 was added. Media were changed every week. After 3 weeks, colonies were stained with crystal violet and the number of cells was counted for five randomly selected fields under the microscope at $40 \times$ magnification. Each group was counted in 3 wells.

\section{Western blotting}

IMR-32 cells $\left(1.0 \times 10^{5}\right.$ cells/well $)$ and MIA-PaCa 2 cells $\left(8.0 \times 10^{4}\right.$ cells/well $)$ were allowed to adhere in 6 -well plates coated with fibronectin. Each treatment is described in the figure legends. Subsequent steps were conducted using antibodies shown among the reagents, as described previously [35].

\section{Immunoprecipitation}

IMR-32 cells were cultured with or without FNIII14 $(50 \mu \mathrm{g} / \mathrm{mL})$ for 6 days. At $24 \mathrm{~h}$ before lysis, Cells were treated with or without MG-132 $(1.0 \mu \mathrm{M})$. Cells were dissolved with the RIPA buffer (25 mM Tris, $15 \mathrm{mM}$ $\mathrm{NaCl}, 1.0 \mathrm{mM}$ EDTA, 1.0\% NP-40, 5.0\% glycerol, $\mathrm{pH}$ 7.4) and prepared protein concentration at $1.0 \mathrm{mg} / \mathrm{mL}$. Cell lysates were added to Anti-N-Myc Ab $5.0 \mu \mathrm{g} / \mathrm{mL}$ or control mouse IgG $5.0 \mu \mathrm{g} / \mathrm{mL}$ and rotated for $1 \mathrm{~h}$ in $4^{\circ} \mathrm{C}$. After being rotated, $20 \mu \mathrm{L}$ Protein G Agarose (Santa Cruz Biotechnology, Inc., Texas, USA) was added to cell lysates and the mixture was rotated overnight at $4^{\circ} \mathrm{C}$. Cell lysates were washed by RIPA buffer 3 times and subjected to western blot analysis using anti-N-Myc Ab, and antiUbiquitin $\mathrm{Ab}$.

\section{In vitro invasion assay}

A transwell chamber was used for the invasion assay. Before preparation, IMR-32 cells $\left(1.0 \times 10^{5}\right.$ cells/ well) were treated with or without FNIII14 $(50 \mu \mathrm{g} / \mathrm{mL})$ on FN-coated 6-well plate for 6 days. Culture medium of $10 \%$ FBS $(200 \mu \mathrm{L})$ was added to the lower chamber and the membrane filter $(8.0 \mu \mathrm{m})$ mentioned above was placed on top. For a basement membrane matrix, EHSgel Basement membrane Matrix (055-09031; Wako Pure Chemicals Corp., Osaka, Japan) including $2.0 \mu \mathrm{g} / \mathrm{mL}$ FN was adjusted to $600 \mu \mathrm{g} / \mathrm{mL}$ with PBS solution, and $100 \mu \mathrm{L}$ was applied to the membrane filter. The EHS-gel Basement membrane Matrix was coated by incubation at $37^{\circ} \mathrm{C}$ in a $5 \% \mathrm{CO}_{2}$ incubator for $1 \mathrm{~h}$. After removing the supernatant of the gel, IMR-32 cells were pre-treated by vehicle or FNIII14 $\left(5.0 \times 10^{4}\right.$ cells/well $)$, seeded, and incubated at $37^{\circ} \mathrm{C}$ in a $5 \% \mathrm{CO}_{2}$ incubator for $24 \mathrm{~h}$. After removing non-permeating cells from the membrane filter with a cotton swab, the invading cells were fixed by a PBS (-) solution including 4\% formalin and 10\% glycerol with the undersurface as the top at room temperature for $1 \mathrm{~h}$. The invading cells were counted in 4 fields under a $100 \times$ microscope after dyeing the cells with crystal violet stain.

\section{Animal study}

All animal procedures were approved by the Institutional Animal Care and Use Committee (IACUC) of Tokyo University of Science. IMR-32 cells $\left(2.0 \times 10^{6}\right.$ cells/head) suspended in MEM plus 5\% FBS with 2.0 $\mathrm{mg} / \mathrm{mL}$ EHS-gel $(200 \mu \mathrm{L})$ were subcutaneously injected into the left flanks of 5-week old male Balb/c nude mice (Sankyo Laboratory Service, Tokyo, Japan). Mice bearing established tumors were divided into two groups, 'Control' and 'FNIII14'. The Control group was intravenously administered with saline and intraperitoneally administered with soybean oil, every other day. The FNIII14 group was intravenously administered with saline solution of peptide FNIII14 $(100 \mu \mathrm{g})$, and intraperitoneally administered with a soybean oil solution of the peptide $(500 \mu \mathrm{g})$, every other day. These procedures were initially performed for 1 week. Tumor volume $\left(\mathrm{mm}^{3}\right)$ determined by calipers was calculated according to hemi-ellipsoid model: Volume $=2 / 3 \times \pi \times($ major axis $/ 2) \times(\text { minor axis } / 2)^{2}$. After monitoring tumor sizes for 4 weeks, they were removed and homogenized in lysis buffer by BioMasher (Nippi Inc., Tokyo, Japan). Cell lysates were subjected to western blot to detect N-Myc and Aurora A. 


\section{Semi-quantitative PCR}

Cell RNA was extracted using the GenElute ${ }^{\mathrm{TM}}$ Mammalian Total RNA Miniprep Kit (Sigma-Aldrich Japan) according to the manufacturer's instructions. After evaluating the RNA concentration by Nano Drop (Thermo Scientific, Danvers, MA), cDNA was gathered by reverse transcription reaction using Quanti Tect ${ }^{\mathbb{R}}$ Reverse Transcription (QIAGEN K.K. - Japan, Tokyo, Japan) and amplified in PCR Thermal Cycler Dicer (Takara Bio, Shiga, Japan) using the specific primers (ITGA4 forward: 5'-GCTTCTCAGATCTGCTCGTG-3', ITGA4 reverse: 5'- GTCACTTCCAACGAGGTTTG-3', ITGA5 forward: 5'-TGCAGTGTGAGGCTGTGTACA-3', ITGA5 reverse: 5'-GTGGCCACCTGACGCTCT-3', ITGAV forward: 5'-GG ATTGTTGCTACTGGCTGTTTTGG-3', ITGAV reverse: 5'-TCCCTTTCTTGTTCTTCTTGAGGTGG-3', ITGB1 forward: 5'-GAAGGGTTGCCCTCCAGA-3', ITGB1 reverse: 5'-GCTTGAGCTTCTCTGCTGTT-3', GAPDH forward: 5'-TTCACCACCATGGAGAAGGC-3', and GAPDH reverse: 5'-GGCATGGACTGTGGTCATGA-3',). The following PCR program was performed: ITGA4, ITGBI and $\mathrm{GAPDH}$, at $94^{\circ} \mathrm{C}$ for $2 \mathrm{~min}$ (initial denaturation), at $94^{\circ} \mathrm{C}$ for $30 \mathrm{~s}$, at $55^{\circ} \mathrm{C}$ for $30 \mathrm{~s}$, at $72^{\circ} \mathrm{C}$ for $40 \mathrm{~s}, 30$ cycles and final extension at $72^{\circ} \mathrm{C}$ for $7 \mathrm{~min}$.; ITGA5 and $I T G A V$, at $94^{\circ} \mathrm{C}$ for $2 \mathrm{~min}$ (initial denaturation), at $94^{\circ} \mathrm{C}$ for $30 \mathrm{~s}$, at $60^{\circ} \mathrm{C}$ for $30 \mathrm{~s}$., at $72^{\circ} \mathrm{C}$ for $40 \mathrm{~s}, 30$ cycles and final extension at $72^{\circ} \mathrm{C}$ for $7 \mathrm{~min}$. The PCR products were electrophoresed using $2 \%$ agarose-TBE gel including ethidium bromide and developed with a trans-illuminator. Semi-quantitative RT-PCR followed by densitometry scanning. GAPDH served as an internal control.

\section{Real-time quantitative PCR}

RNA extraction and cDNA synthesis were mentioned as above. Real-time polymerase chain reactions were performed on a CFX Connect ${ }^{\mathrm{TM}}$ Real-Time PCR system (Bio-Rad Laboratories, Hercules, CA) and using THUNDERBIRD ${ }^{\circledR}$ SYBR $^{\circledR}$ qPCR Mix (Toyobo Co., Ltd., Osaka, Japan) and these specific primers: $M Y C N$ forward: 5'-CGACCACAAGGCCCTCAGTA-3', MYCN reverse: 5'-CAGCCTTGGTGTTGGAGGAG-3', GAPDH forward: 5'-TTCACCACCATGGAGAAGGC-3', GAPDH reverse: 5'-GGCATGGACTGTGGTCATGA-3'.

\section{Cell adhesion assay}

IMR-32 cells were harvested and suspended $\left(1 \times 10^{4}\right.$ cells/well $)$ in serum-free medium with FNIII14 $(50 \mu \mathrm{g} / \mathrm{mL})$ on fibronectin substrate $(2 \mu \mathrm{g} / \mathrm{mL})$. Cells were incubated in a $96-$ well plate in a $5 \% \mathrm{CO}_{2}$ incubator at $37^{\circ} \mathrm{C}$ for $45 \mathrm{~min}$. Adhered cells were fixed with $4 \%$ formalin and $5 \%$ glycerol. Fixed cells were counted and the number of spread and attached cells in 4 fields of each well were counted.

\section{Flow cytometric analysis}

Active $\beta 1$-integrins on the cells were evaluated by flow cytometric analysis using anti- $\beta 1$-integrin antibody (Clone: AG89) conjugated with phycoerythrin (Medical \& Biological Laboratories Co., Ltd., Nagoya, Japan), which recognizes the active conformation-specific epitope of $\beta 1$-integrin, and BD FACS Aria (BD Bioscience) as previously described.

\section{Statistical analysis}

Data are expressed as means \pm standard deviation. Two-tailed Student's $t$-test or one-way analysis of variance was used to determine statistical differences. Values of $P<$ 0.05 were considered statistically significant.

\section{Author contributions}

MS, NK, TA, and SS performed experiments. MS and FF analyzed the data and drafted the manuscript. YS, TI, KH, SY, and YI assisted with the analysis and provided constructive discussions. FF designed the experiments. All authors read and approved the final manuscript.

\section{ACKNOWLEDGMENTS AND FUNDING}

This study was performed as a translational research program, part of a strategic promotion for practical application of innovative medical technology by Tsukuba University and was supported by AMED under Grant Number JP18Im0203010.

\section{CONFLICTS OF INTEREST}

There are no conflicts of interest to disclose.

\section{REFERENCES}

1. Stine ZE, Walton ZE, Altman BJ, Hsieh AL, Dang CV. MYC, Metabolism, and Cancer. Cancer Discov. 2015; 5:1024-39. https://doi.org/10.1158/2159-8290.CD-15-0507. [PubMed]

2. Dang CV. MYC on the path to cancer. Cell. 2012; 149:2235. https://doi.org/10.1016/j.cell.2012.03.003. [PubMed]

3. Goetzman ES, Prochownik EV. The Role for Myc in Coordinating Glycolysis, Oxidative Phosphorylation, Glutaminolysis, and Fatty Acid Metabolism in Normal and Neoplastic Tissues. Front Endocrinol (Lausanne). 2018; 9:129. https://doi.org/10.3389/fendo.2018.00129. [PubMed]

4. Beltran H. The N-myc Oncogene: Maximizing its Targets, Regulation, and Therapeutic Potential. Mol Cancer Res. 2014; 12:815-22. https://doi.org/10.1158/1541-7786.MCR13-0536. [PubMed] 
5. Esposito MR, Aveic S, Seydel A, Tonini GP. Neuroblastoma treatment in the post-genomic era. J Biomed Sci. 2017; 24:14. $\quad$ https://doi.org/10.1186/s12929-017-0319-y. [PubMed]

6. Matthay KK, Maris JM, Schleiermacher G, Nakagawara A, Mackall CL, Diller L, Weiss WA. Neuroblastoma. Nat Rev Dis Primers. 2016; 2:16078. https://doi.org/10.1038/ nrdp.2016.78. [PubMed]

7. Greengard EG. Molecularly Targeted Therapy for Neuroblastoma. Children (Basel). 2018; 5. https://doi. org/10.3390/children5100142. [PubMed]

8. Witkiewicz AK, McMillan EA, Balaji U, Baek G, Lin WC, Mansour J, Mollaee M, Wagner KU, Koduru P, Yopp A, Choti MA, Yeo CJ, McCue P, et al. Whole-exome sequencing of pancreatic cancer defines genetic diversity and therapeutic targets. Nat Commun. 2015; 6:6744. https:// doi.org/10.1038/ncomms7744. [PubMed]

9. Brägelmann J, Böhm S, Guthrie MR, Mollaoglu G, Oliver TG, Sos ML. Family matters: how MYC family oncogenes impact small cell lung cancer. Cell Cycle. 2017; 16:148998. https://doi.org/10.1080/15384101.2017.1339849. [PubMed]

10. Zheng K, Cubero FJ, Nevzorova YA. c-MYC-Making Liver Sick: Role of c-MYC in Hepatic Cell Function, Homeostasis and Disease. Genes (Basel). 2017; 8. https:// doi.org/10.3390/genes8040123. [PubMed]

11. Chen H, Liu H, Qing G. Targeting oncogenic Myc as a strategy for cancer treatment. Signal Transduct Target Ther. 2018; 3:5. https://doi.org/10.1038/s41392-018-0008-7. [PubMed]

12. Horiuchi D, Anderton B, Goga A. Taking on challenging targets: making MYC druggable. Am Soc Clin Oncol Educ Book. 2014; 34:e497-502. https://doi.org/10.14694/ EdBook AM.2014.34.e497. [PubMed]

13. Vega ME, Schwarzbauer JE. Collaboration of fibronectin matrix with other extracellular signals in morphogenesis and differentiation. Curr Opin Cell Biol. 2016; 42:1-6. https://doi.org/10.1016/j.ceb.2016.03.014. [PubMed]

14. Wolfenson H, Lavelin I, Geiger B. Dynamic regulation of the structure and functions of integrin adhesions. Dev Cell. 2013; 24:447-58. https://doi.org/10.1016/j. devcel.2013.02.012. [PubMed]

15. Bornstein P, Sage EH. Matricellular proteins: extracellular modulators of cell function. Curr Opin Cell Biol. 2002; 14:608-16. https://doi.org/10.1016/S0955-0674(02)003617. [PubMed]

16. Fukai F, Takahashi H, Habu Y, Kubushiro N, Katayama T. Fibronectin harbors anticell adhesive activity. Biochem Biophys Res Commun. 1996; 220:394-98. https://doi. org/10.1006/bbrc.1996.0416. [PubMed]

17. Kato R, Ishikawa T, Kamiya S, Oguma F, Ueki M, Goto S, Nakamura H, Katayama T, Fukai F. A new type of antimetastatic peptide derived from fibronectin. Clin Cancer Res. 2002; 8:2455-62. [PubMed]
18. Itagaki K, Naito T, Iwakiri R, Haga M, Miura S, Saito Y, Owaki T, Kamiya S, Iyoda T, Yajima H, Iwashita S, Ejiri $\mathrm{S}$, Fukai F. Eukaryotic translation elongation factor 1A induces anoikis by triggering cell detachment. J Biol Chem. 2012; 287:16037-46. https://dx.doi.org/10.1074\%2Fjbc. M111.308122 https://doi.org/10.1074/jbc.M111.308122. [PubMed]

19. Iyoda T, Nagamine Y, Nakane Y, Tokita Y, Akari S, Otsuka K, Fujita M, Itagaki K, Takizawa Y, Orita H, Owaki T, Taira J, Hayashi R, et al. Coadministration of the FNIII14 Peptide Synergistically Augments the Anti-Cancer Activity of Chemotherapeutic Drugs by Activating Pro-Apoptotic Bim. PLoS One. 2016; 11:e0162525. https://doi.org/10.1371/ journal.pone.0162525. [PubMed]

20. Matsunaga T, Fukai F, Miura S, Nakane Y, Owaki T, Kodama H, Tanaka M, Nagaya T, Takimoto R, Takayama T, Niitsu Y. Combination therapy of an anticancer drug with the FNIII14 peptide of fibronectin effectively overcomes cell adhesion-mediated drug resistance of acute myelogenous leukemia. Leukemia. 2008; 22:353-60. https://doi.org/10.1038/sj.leu.2405017. [PubMed]

21. Alaminos M, Mora J, Cheung NK, Smith A, Qin J, Chen L, Gerald WL. Genome-wide analysis of gene expression associated with MYCN in human neuroblastoma. Cancer Res. 2003; 63:4538-46. [PubMed]

22. Mould AP, Askari JA, Barton S, Kline AD, McEwan PA, Craig SE, Humphries MJ. Integrin activation involves a conformational change in the $\alpha 1$ helix of the $\beta$ subunit A-domain. J Biol Chem. 2002; 277:19800-05. https://doi. org/10.1074/jbc.M201571200. [PubMed]

23. Mould AP, Barton SJ, Askari JA, McEwan PA, Buckley PA, Craig SE, Humphries MJ. Conformational changes in the integrin beta A domain provide a mechanism for signal transduction via hybrid domain movement. J Biol Chem. 2003; 278:17028-35. https://doi.org/10.1074/jbc. M213139200. [PubMed]

24. Sjostrom SK, Finn G, Hahn WC, Rowitch DH, Kenney AM. The Cdk1 complex plays a prime role in regulating $\mathrm{N}$-myc phosphorylation and turnover in neural precursors. Dev Cell. 2005; 9:327-38. https://doi.org/10.1016/j. devcel.2005.07.014. [PubMed]

25. Otto T, Horn S, Brockmann M, Eilers U, Schüttrumpf L, Popov N, Kenney AM, Schulte JH, Beijersbergen R, Christiansen H, Berwanger B, Eilers M. Stabilization of N-Myc is a critical function of Aurora A in human neuroblastoma. Cancer Cell. 2009; 15:67-78. https://doi. org/10.1016/j.ccr.2008.12.005. [PubMed]

26. Xiao D, Yue M, Su H, Ren P, Jiang J, Li F, Hu Y, Du H, Liu H, Qing G. Polo-like Kinase-1 Regulates Myc Stabilization and Activates a Feedforward Circuit Promoting Tumor Cell Survival. Mol Cell. 2016; 64:493-506. https://doi. org/10.1016/j.molcel.2016.09.016. [PubMed]

27. Zeid R, Lawlor MA, Poon E, Reyes JM, Fulciniti M, Lopez MA, Scott TG, Nabet B, Erb MA, Winter GE, Jacobson 
Z, Polaski DR, Karlin KL, et al. Enhancer invasion shapes MYCN-dependent transcriptional amplification in neuroblastoma. Nat Genet. 2018; 50:515-23. https://doi. org/10.1038/s41588-018-0044-9. [PubMed]

28. Kaneko Y, Suenaga Y, Islam SM, Matsumoto D, Nakamura Y, Ohira M, Yokoi S, Nakagawara A. Functional interplay between MYCN, NCYM, and OCT4 promotes aggressiveness of human neuroblastomas. Cancer Sci. 2015; 106:840-47. https://doi.org/10.1111/cas.12677. [PubMed]

29. Humphries JD, Byron A, Humphries MJ. Integrin ligands at a glance. J Cell Sci. 2006; 119:3901-03. https://doi. org/10.1242/jcs.03098. [PubMed]

30. Zhang YY, Kong LQ, Zhu XD, Cai H, Wang CH, Shi WK, Cao MQ, Li XL, Li KS, Zhang SZ, Chai ZT, Ao JY, Ye BG, Sun HC. CD31 regulates metastasis by inducing epithelialmesenchymal transition in hepatocellular carcinoma via the ITGB1-FAK-Akt signaling pathway. Cancer Lett. 2018; 429:29-40. https://doi.org/10.1016/j.canlet.2018.05.004. [PubMed]

31. Gregory MA, Hann SR. c-Myc proteolysis by the ubiquitin-proteasome pathway: stabilization of c-Myc in Burkitt's lymphoma cells. Mol Cell Biol. 2000; 20:242335. https://doi.org/10.1128/MCB.20.7.2423-2435.2000. [PubMed]
32. Greenwood JA, Murphy-Ullrich JE. Signaling of de-adhesion in cellular regulation and motility. Microsc Res Tech. 1998; 43:420-32. https://doi.org/10.1002/(SICI)10970029(19981201)43:5<420::AID-JEMT8>3.0.CO;2-B. [PubMed]

33. Miekka SI, Ingham KC, Menache D. Rapid methods for isolation of human plasma fibronectin. Thromb Res. 1982; 27:1-14. https://doi.org/10.1016/0049-3848(82)90272-9. [PubMed]

34. Saito Y, Owaki T, Matsunaga T, Saze M, Miura S, Maeda M, Eguchi M, Tanaka R, Taira J, Kodama H, Goto S, Niitsu Y, Terada H, Fukai F. Apoptotic death of hematopoietic tumor cells through potentiated and sustained adhesion to fibronectin via VLA-4. J Biol Chem. 2010; 285:7006-15. https://doi.org/10.1074/jbc.M109.027581. [PubMed]

35. Saito Y, Imazeki H, Miura S, Yoshimura T, Okutsu H, Harada Y, Ohwaki T, Nagao O, Kamiya S, Hayashi R, Kodama H, Handa H, Yoshida T, Fukai F. A peptide derived from tenascin- $\mathrm{C}$ induces $\beta 1$ integrin activation through syndecan-4. J Biol Chem. 2007; 282:34929-37. https://doi. org/10.1074/jbc.M705608200. [PubMed] 